\title{
実タイヤの内面変形量によるタイヤ一路面間の摩擦係数の推定 Estimation of Coefficient of Friction between the Tire and Road according to Deformation of the Inner Surface of the Tire
}

\author{
○学 金谷 圭一朗（金沢大）正 岩井 智昭（金沢大） 非 正角 豊（金沢大）
}

Keiichiro KANAYA, Graduate School of Natural Science of Technology, Kanazawa University, Kakuma, Kanazawa, Ishikawa

Tomoaki IWAI, School of Mechanical Engineering, Kanazawa University, Kakuma, Kanazawa, Ishikawa Yutaka SHOUKAKU, School of Mechanical Engineering, Kanazawa University, Kakuma, Kanazawa, Ishikawa

Key Words: Tire/road friction, parallel stereo method, deformation of a tire

\section{1. 諸言}

近年, 自動車走行の安全性と快適性の向上から, タイヤ の状態をリアルタイムで計測するインテリジェントタイヤ の必要性が高まっており, 中でもタイヤ一路面間の摩擦係 数を計測可能なインテリジェントタイヤに関する研究が進 められている. 摩擦係数を計測する方法の 1 つとして, 夕 イヤ内面にひずみセンサ等を設置してタイヤ内面の変形を 計測する手法が提案されている。しかし, タイヤ内面にセ ンサを設置することはタイヤ自身の変形を阻害したり，タ イヤの変形によってセンサが剥離してしまうなどの問題点 を生じさせている，そこで本研究では，ステレオカメラを ホイールリムに取り付け，光学的手法である三角法を用い てタイヤ内面の三次元的変形をタイヤ内面に対して非接触 で計測し，タイヤ内面の変形とタイヤ一路面間の摩擦係数 との関係を調べた。そしてその関係を用いて摩擦係数の推 定を試みた。

\section{2. 実験方法}

Figure 1 に実験装置を示す.相手面を $z$ 方向に上下させる ことによってタイヤと接触させ垂直荷重を与えるとともに, モータでタイヤを回転させ， $x$ 方向に摩擦力を生じさせる. 摩擦力は相手面下の八角弾性リングに張り付けたひずみゲ ージより出力されるひずみから求める. 実験では市販ラジ アルタイヤ(145/80 R13)を使用した. 相手面は, アルミニウ ム板，PTFE シート，研磨紙 CC\#80 である。また，Fig.2 に 示すように摩擦力による $x$ 方向の変位を $\Delta x$ とし, 垂直荷 重による $z$ 方向の変位を $\Delta r$ とする. なお本研究では $y$ 方 向の横力による変形は考慮しない. 各実験では, 半径方向 の変形量 $\Delta r$ とタイヤ円周方向の変形量 $\Delta x$ を測定するが, このときの変形量は荷重無負荷時のタイヤ底部の測定点の

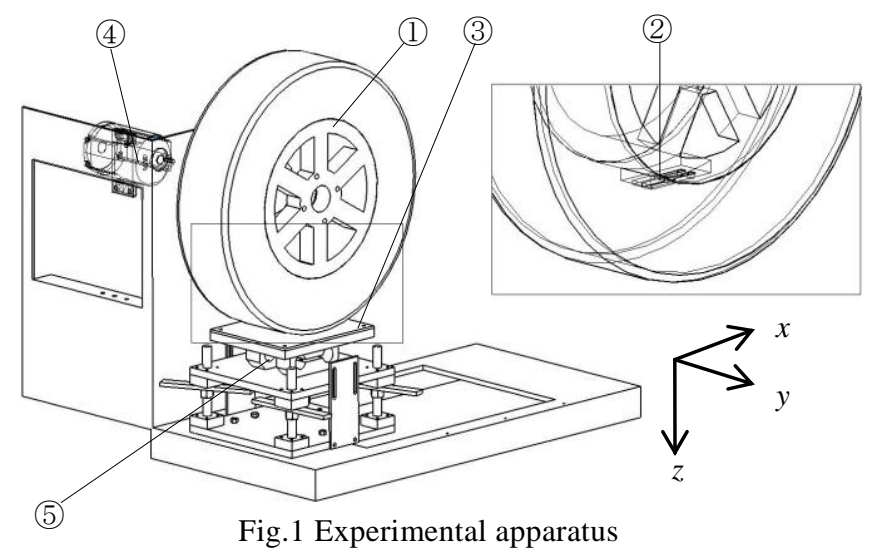

1, tire and wheel; 2, stereo camera; 3, mating surface;

4 , motor; 5, elastic ring
変位量から求める。最初に, 静的負荷を与えた場合の, 荷 重 $W$ とタイヤ円周方向変形 $\Delta r$ の関係を調べた. 実験では, タイヤを固定して相手面を $z$ 方向に上昇させてタイヤに荷 重を加える.このとき加えた荷重 $W$ は荷重とタイヤ半径方 向変形の関係を求める実験においては 490.5N, 686.7N, $981.0 \mathrm{~N}$, および $1275 \mathrm{~N}$, 夕イヤ内面の変形と摩擦係数, 接 線力係数の関係を求める実験においては $392.4 N, 294.3 \mathrm{~N}$ で ある。

\section{3. 測定原理}

本研究では, タイヤ内面の変形の測定に平行ステレオ法 を用いた. Figure 3 に平行ステレオ法について示す.この 手法では， 2 台の平行に設置したカメラ(ステレオカメラ) から得られた画像により, 三角測量の原理で測定点の三次 元位置を計測する。ステレオカメラで同一測定点を撮影す ると, 測定点は左画像平面では $\left(u_{l}{ }_{l}, v^{\prime}{ }_{l}\right)$, 右画像平面では $\left(u_{r}\right.$, $\left.v_{r}\right)$ に撮影される.このとき, Fig.3に示されるように，画像 水平方向に差が生じる。 この差を視差 $d$ といい, 式(1)で表 される

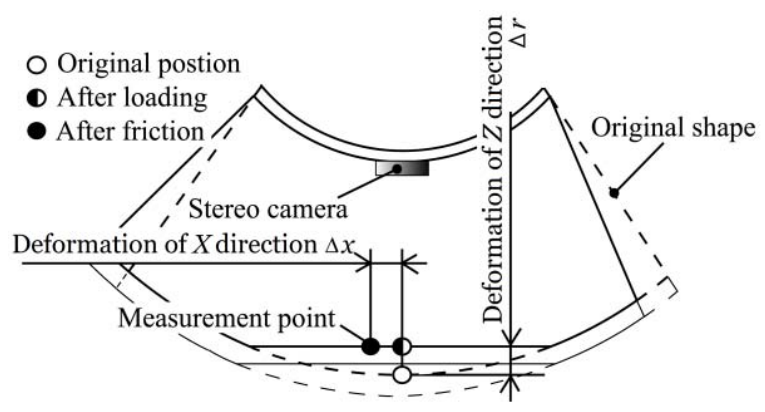

Fig. 2 The deformation of a tire

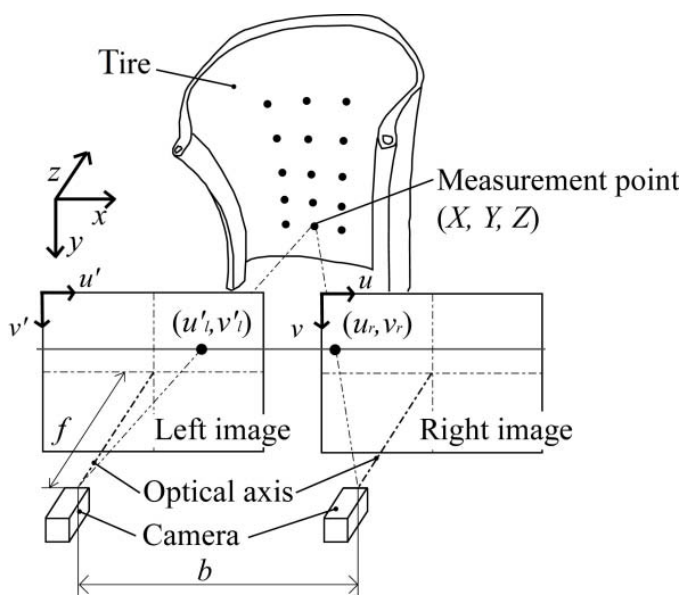

Fig.3 Diagram of the parallel stereo method 


$$
d=u^{\prime}{ }_{l}-u_{r}
$$

この視差 $d$ を用いると, 测定点の三次元位置 $(X, Y, Z)$ は式(2) によって求められる.

$$
\left[\begin{array}{l}
X \\
Y \\
Z
\end{array}\right]=\left[\begin{array}{l}
u_{r} b / d \\
v_{r} b / d \\
f b / d
\end{array}\right]
$$

ここで, $b$ はカメラ間距離, $f$ は焦点距離である.

タイヤ内面に等閒隔でマークした複数個の測定点の三次 元位置を測定することで，タイヤの断面形状を三次元的に 測定することが可能である。

\section{4. 実験結果}

\section{4・1 荷重とタイヤ半径方向変形の関係}

静的状態でタイヤに荷重を加えたときの半径方向変形量 $\Delta r$ を計測した. 内圧が $200 \mathrm{kPa}$ の時の負荷荷重 $W$ と半径方 向変形量 $\Delta r$ の関係を Fig.4 に示寸. 試料に加える荷重が増 加すると半径方向変形量 $\Delta r$ も増加することがわかる．ま た，相手面の違いによる影響は見られなかった．

4. 2 タイヤ内面の変形と摩擦係数, 接線力係数の関係 タイヤに荷重を加え, 内圧を変化させてしゅう動させた ときの, タイヤ内面の変形と摩擦係数および接線力係数を 測定した. 円周方向変形量 $\Delta x$ を半径方向変形量 $\Delta r$ で除 した值 $\Delta x / \Delta r$ と摩擦係数, 接線力係数の関係を Fig. 5 に示 す. タイヤ内面の変形が増加すると摩擦係数も増加する傾 向が見られた。そして，摩擦係数，接線力係数は内圧の大 きさによらず, タイヤ内面の変形 $\Delta x / \Delta r$ に線形な関係とな る.また, Fig.6よりこの推定值は摩擦係数, 接線力係数の

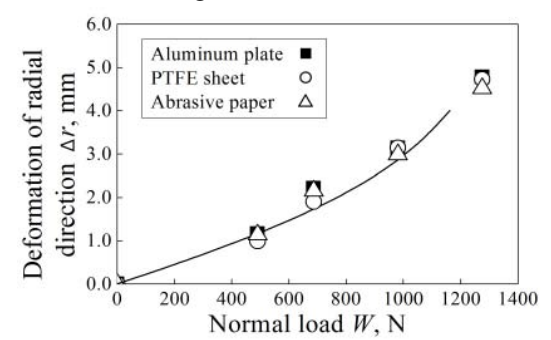

Fig.4 Relationship between normal load $W$ and deformation of radial direction $\Delta r$

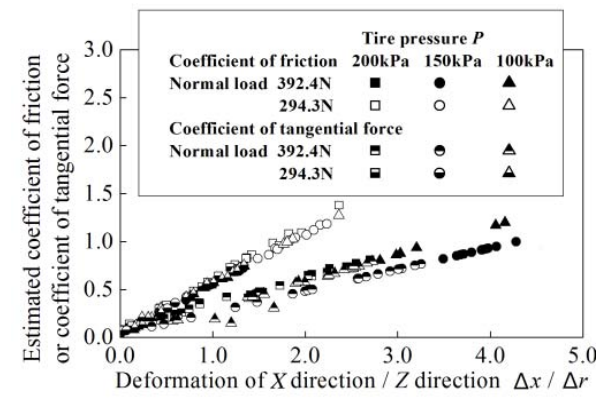

Fig. 5 The coefficient of friction as a

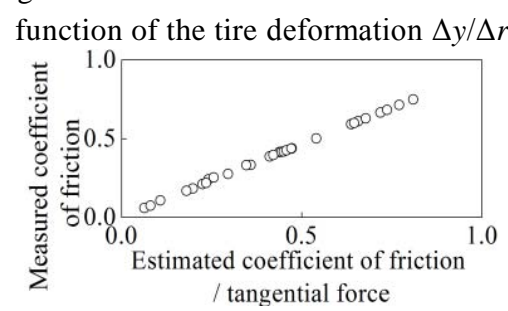

Fig. 6 Comparison of estimated and measured coefficient of friction
実測值と比べてもほぼ一致する. 以上の結果より, タイヤ 内面の変形々摩擦係数には, 明確な関係が存在することが 明らかになった。したがって, 走行中のタイヤ内面の変形 を測定することで, タイヤ一相手面間摩擦係数の推定が可 能であるといえる.

\section{$\mathbf{4} \cdot 3$ 摩擦係数の推定}

以上の結果をもとに摩擦係数の推定を行った. タイヤの 半径方向変形量変形量 $\Delta r$ および円周方向変形量 $\Delta x$ を測 定し, 既知の $\Delta x / \Delta r$ と摩擦係数の関係から未知の摩擦係数 を推定する. 推定条件は, 荷重 $W=393.4 \mathrm{~N}$, 内圧 $P=200 \mathrm{kPa}$, 荷重 $W=294.3 \mathrm{~N}$, 内圧 $P=200 \mathrm{kPa}$, 荷重 $W=363.0 \mathrm{~N}$, 内圧 $P=180 \mathrm{kPa}$ および荷重 $W=314.0 \mathrm{~N}$, 内圧 $P=125 \mathrm{kPa}$ である. 摩擦係数の推定結果を Fig. 7 に示す。いずれの条件におい ても, 摩擦係数の推定值はどの相手面でも多少の誤差はあ るが測定值と一致していることがわかる。したがって，タ イヤ内面の変形を測定することで転動するタイヤの摩擦係 数の推定が可能である.

5. 結言

タイヤの摩擦における変形を平行ステレオ法で測定した 結果，以下のことが分かった。

(1) 平行ステレオ法を用いて, 空気入り実タイヤの内面の 3 次元的変形が測定可能である.

（2）タイヤと相手面をしゅう動させた場合，タイヤ内面の 変形 $\Delta x / \Delta r$ と摩擦係数には線形な関係があり, タイヤ 内面の変形から摩擦係数を求めることが可能である.

(3) タイヤ内面の変形量測定を用いて, 摩擦係数の推定が 可能である.

$\begin{array}{lccc} & \text { Aluminum plate PTFE sheet } & \text { Abrasive paper } \\ \text { Measured } & -\cdot- & -\cdot-\end{array}$

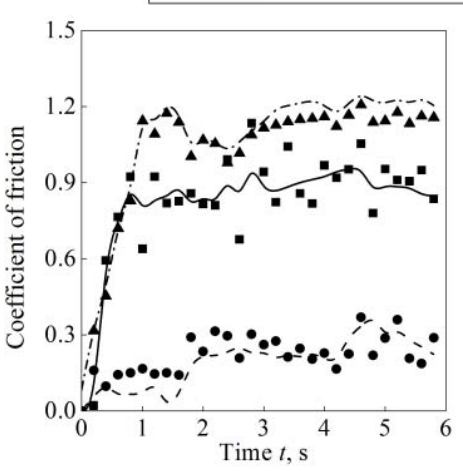

(a) Normal load $W=393.4 \mathrm{~N}$, Tire pressure $P=200 \mathrm{kPa}$

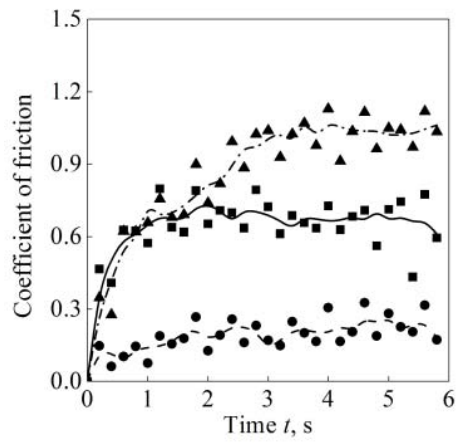

(c) Normal load $W=363.0 \mathrm{~N}$, Tire pressure $P=180 \mathrm{kPa}$

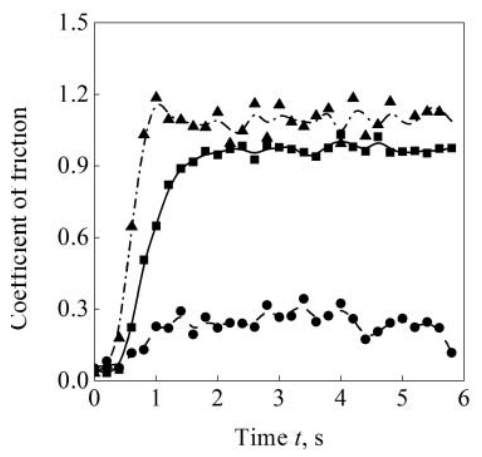

(b) Normal load $W=294.3 \mathrm{~N}$, Tire pressure $P=200 \mathrm{kPa}$

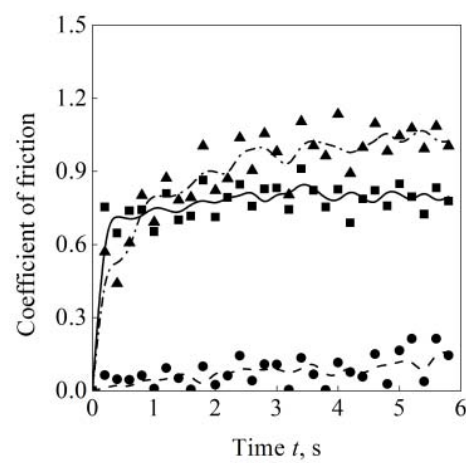

(d) Normal load $W=314.0 \mathrm{~N}$, Tire pressure $P=125 \mathrm{kPa}$
Fig.7 Comparison of estimated and measured coefficient of friction 